PDFlib PLOP: PDF Linearization, Optimization, Protection

Page inserted by evaluation version www.pdflib.com - sales@pdflib.com 


\title{
Insulin-like Growth Factor Binding Protein Expression in Human Retinal Pigment Epithelial Cells
}

\author{
ANN RANDOLPH, DOUGLAS YEE, ${ }^{a}$ \\ AND EVA L. FELDMAN \\ University of Michigan Medical Center \\ Ann Arbor, Michigan 48109 \\ ${ }^{a}$ University of Texas Health Science Center \\ San Antonio, Texas 78284
}

Insulin-like growth factors I and II (IGF-I and -II) are polypeptides that play an important role in cellular growth and differentiation.' The actions of IGF-I and -II are modulated, in part, by a family of high-affinity IGF binding proteins, designated IGFBPs. ${ }^{1}$ IGFBPs transport IGFs, modulate IGF tissue availability, and alter IGF

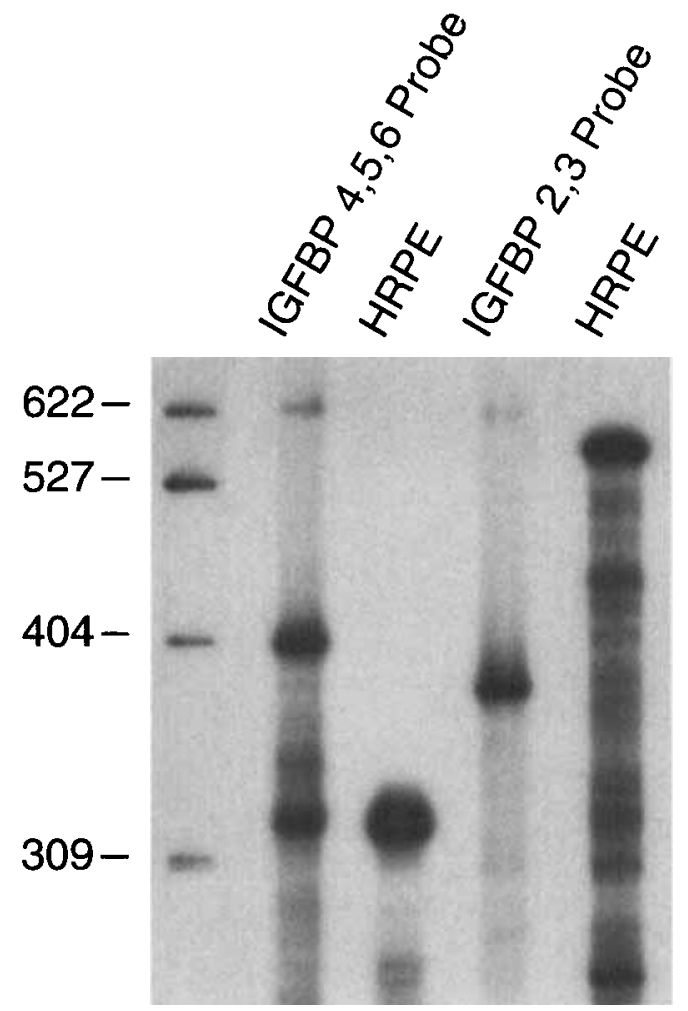

FIGURE 1. IGFBP RNase protection assay in cultured HRPE cells. The $c$ RNA probes used to detect IGFBP mRNA were transcribed from different portions of the cDNAs; A 267 and a 535 bp fragment were protected, corresponding to IGFBP-6 and IGFBP-3 respectively. 
receptor binding. ${ }^{1}$ Epithelial cells provide a good in vitro model system for examining IGFBP physiology. ${ }^{1}$ During development, IGFs are primarily synthesized in mesenchymal cells, but are localized by immunocytochemical studies to epithelial cells. ${ }^{2}$ This discrepancy between IGF synthesis and localization implies transport of IGFs to epithelial cells by IGFBPs. IGFBPs are also immunolocalized to epithelial cells, ${ }^{3}$ however, little is known about the potential mechanisms directing synthesis and secretion of binding proteins by these cells. One attractive hypothesis is that epithelial secretion of IGFBPs allows targeting of IGFs and concomitant growth. ${ }^{3}$ As an initial step towards understanding IGFBP function, we examined the pattern of IGFBP gene and protein expression in human retinal pigment epithelial (HRPE) cells.

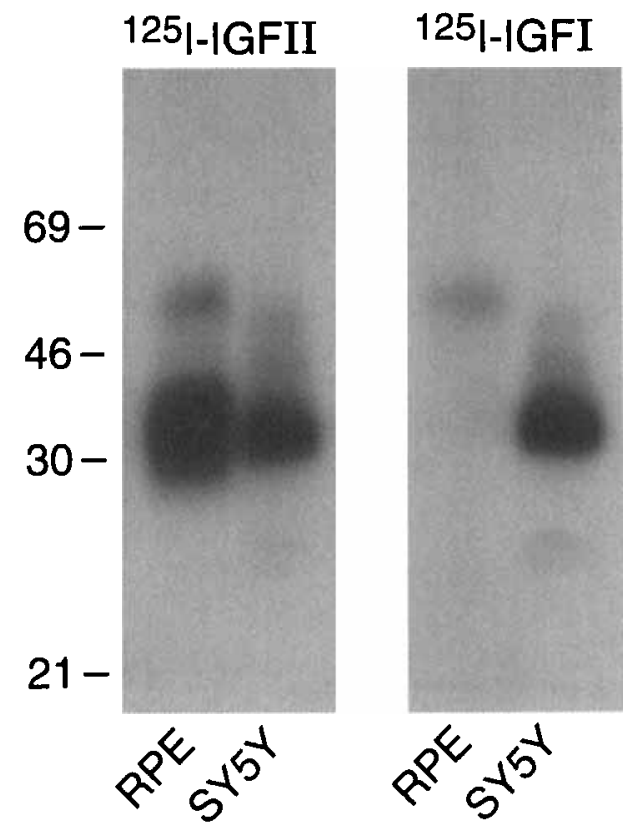

FIGURE 2. Ligand blot analysis of HRPE conditioned medium (CM). CM from either HRPE cells or control SH-SY5Y neuroblastoma cells was concentrated 20-fold and electrophoresed through a $10 \%$ sodium dodecyl sulfate-polyacrylamide gel under nonreducing conditions. Proteins were electroblotted onto a nitrocellulose membrane and exposed to either ${ }^{125}$ I-IGF-I or -II.

Primary HRPE cell cultures were established and maintained as previously described. ${ }^{4}$ Total cellular RNA was isolated from cells using guanidinium thiocyanatephenol extraction for RNase protection assays. ${ }^{4,5} \mathrm{cDNA}$ clones were obtained from Dr. S. Shimasaki (IGFBP-2, 4, 5, 6) and Dr. D. Powell (IGFBP-1, 3). In some experiments, HRPE cells were grown under serum-free conditions and conditioned medium was analyzed by western ligand blot analysis. ${ }^{3}$

RNase protection of HRPE total RNA revealed two protected fragments, corresponding to IGFBP-3 and IGFBP-6. No protected fragments were observed with IGFBP-2, 4, or 5 (FIGURE 1). IGFBP-3 gene expression has been reported in 
kidney ${ }^{3}$ and breast epithelia, ${ }^{5}$ while the presence of IGFBP6 transcripts represents a novel observation in epithelial cells.

HRPE cells secreted two IGFBPs, with estimated molecular weights of 34,000 and 46,000 (FIGURE 2). The $46,000 M_{\mathrm{r}}$ band was the more abundantly secreted protein and likely corresponds to IGFBP-3. IGFBP-3 is the most prevalent IGFBP in the circulation and serves as the major transporter of both IGF-I and -II. Constitutive secretion of IGFBP-3 occurs in bovine kidney ${ }^{3}$ and human breast epithelia. ${ }^{5}$

Both IGFBP-2 and IGFBP-6 have estimated molecular weights of 34,000; when visualized by ligand blotting, IGFBP-2 routinely binds either ${ }^{125}$ I-IGF-I or -II, while IGFBP-6 selectively binds ${ }^{125} \mathrm{I}-\mathrm{IGF}-\mathrm{II} .{ }^{6}$ To determine if the $34,000 M_{\mathrm{r}}$ band represented secretion of IGFBP-2 or IGFBP-6, blots were probed with both ${ }^{125}$ I-IGF-I and IGF-II (FIGURE 2). When 125I-IGF-I was used as the probe, only the $46,000 M_{\mathrm{r}}$ band was visualized; in contrast, when blots were probed with ${ }^{125}$ I-IGF-II, both bands were visualized. This differential binding with ${ }^{125}$ I-IGF-I and -II implies that the $34,000 M_{\mathrm{r}}$ form represents IGFBP-6.

In summary, cultured HRPE cells secrete two IGFBPs with $M_{\mathrm{r}}$ estimates of 46,000 and 34,000 and express the genes for IGFBP-3 and IGFBP-6. We are currently examining the regulation of this expression as well as the physiological roles of the IGFBPs in HRPE cells.

\section{REFERENCES}

1. SaRA, V. R. \& K. Hall. 1990. Insulin-like growth factors and their binding proteins Physiol. Rev. 70: 591-614.

2. D'Ercole, A. J. 1991. The insulin-like growth factors and fetal growth. In Modern Concepts of Insulin-Like Growth Factors. E. Martin Spencer, Ed.: 9-23. Elsevier Science Publishing Co. New York, N.Y.

3. COHICK, W. S. \& D. R. ClEmmons. 1991. Regulation of insulin-like growth factor binding protein synthesis and secretion in a bovine epithelial cell line. Endocrinology 129: 13471354.

4. Martin, D. M., D. YeE \& E. L. Feldman. 1992. Gene expression of the insulin-like growth factors and their receptors in cultured human retinal pigment epithelial cells. Mol. Brain Res. 12: 181-186.

5. Yee, D., R. E. Favoni, M. E. Lippman \& D. R. Powell. 1991. Identification of insulin-like growth factor binding proteins in breast cancer cells. Breast Cancer Res. Treat. 18: 3-10.

6. BaCh, L., N. R. Thotakura \& M. M. Rechler. 1992. Human insulin-like growth factor binding protein is $o$-glycosylated. Biochem. Biophys. Res. Comm. 186: 301-307. 